\title{
Primaries and Candidates: Examining the Influence of Primary Electorates on Candidate Ideology*
}

\author{
Lindsay Nielson \\ Bucknell University
}

Neil Visalvanich

Durham University

September 24, 2015

\begin{abstract}
Primary elections in the United States have been under-studied in the political science literature. Using new data to estimate the ideal points of primary election candidates and constituents, we examine the link between the ideological leanings of primary electorates and the ideological orientation of U.S. congressional candidates. We use district-level data from the Cooperative Congressional Election Study and ideal point estimates for congressional primary election candidates to examine the role of primary electorate ideology in the selection of party nominees. We find that more extreme Republicans are more likely to win their party's primary and that Republican and Democratic candidates are responsive to different electoral constituencies.
\end{abstract}

*Authors' Note: Authors are listed in alphabetical order. Correspondence can be addressed to lindsay.nielson@bucknell.edu. We gratefully thank Gary C. Jacobson, Thad Kousser, the journal editors, and the anonymous reviewers for their many helpful comments. We also thank Adam Bonica for providing data on candidate ideal points, Stephen Pettigrew for providing data on candidate characteristics, and Christopher F. Karpowitz, J. Quin Monson, Kelly D. Patterson, and Jeremy C. Pope for providing data on 2010 Tea Party endorsements. All interpretations of the data are the sole responsibility of the authors. A previous version of this paper was presented at the 2012 annual meetings of the Midwest Political Science Association. 
Primary elections are an important - though overlooked - step in the American electoral process, particularly in Congressional elections. Most candidates who wish to run in a general election must first be nominated by their political party, and the outcomes of primaries do a great deal to set the stage for general elections. However, there is little attention given to primaries in empirical research and scant evidence of the relationship between the preferences of primary electorates and the ideologies of the candidates they elect.

Primaries tend to draw participation from activist voters who are more ideologically extreme than general election voters at large or even general election voters of the same party affiliation (Kaufmann, Gimpel and Hoffman, 2003). However, because there are few ways of consistently measuring the ideological preferences of candidates who participate in primaries, scholars have been left guessing whether the preferences of candidates who win primaries more closely match the preferences of their primary electorate or their general electorate.

Our study addresses this lapse in the literature. We use new measures of the ideal points of primary candidates to analyze whether the ideology of a primary electorate influences the ideologies of the candidates who run in primaries. Examining data from the 2008 and 2010 elections for the U.S. House of Representatives, we find that the ideologies of primary and partisan general electorates are significant predictors of a candidate's ideological views. This result holds when we control for incumbency, primary type, and multiple measures of electoral competitiveness. These ideological influences help determine which candidate wins the primary, as primary electorate extremity correlates positively with the primary winner's extremity. We also find differences in the electoral constituencies to which Republican and Democratic candidates respond. 


\section{Candidates and Constituencies}

Within the literature on elections, primaries have not received the same attention as general elections. Nevertheless, they are a vital part of the election process. Primary elections became popular in the early twentieth century as a way to give ordinary citizens more control over elections; previously, candidates were largely selected by political parties. In this study we focus on primaries for the U.S. House of Representatives.

House members require electoral support from many constituencies (Fenno, 1978). Members of Congress are incentivized to be responsive to their constituents because it helps ensure their ultimate goal of re-election (Mayhew, 1974). We propose that primary electorates are a crucial constituency for congressional candidates because members can only run for re-election if they are first nominated in the primary.

Primary voters differ from general voters in their demographics, political preferences, and engagement levels. Primaries lack party cues and attract less media coverage, so they tend to attract more politically engaged, partisan, and ideologically extreme voters than do general elections (Kaufmann, Gimpel and Hoffman, 2003; Fiorina, Abrams and Pope, 2006, Abramowitz and Saunders, 2008). These primary voters may draw candidates' attention because elected officials tend to represent the interests of engaged constituents more than disengaged constituents (Bafumi and Herron, 2010; Burden, 2004).

Politicians are strategic in appealing to their constituents (Fenno, 1978) and seek to maximize their chances of winning (Jacobson and Kernell, 1983). Thus, politicians are incentivized to appeal to primary voters rather than more moderate general election voters (Brady, Han and Pope, 2007; Keele and Stimson, 2005; King, 2003). As primary voters become more ideological, parties may respond by running more ideological candidates (Jacobson, 2004). This could encourage more extremity in primary electorates because moderate voters would be less motivated to turn out if there were no ideologically proximate candidates to vote for (Callender and Wilson, 2007). 
In addition to electorate ideology, primary type may play a role in determining candidate ideology. Prior studies have argued that primary rules affect political party platforms (Gerber and Morton, 1998; Brady and Schwartz, 1995; Westley, Calcagno and Ault, 2004; Besley and Case, 2003) and the types of voters who participate in the primary (Jewell, 1984; Calcagno and Westley, 2008). The relationship between primary rules and candidate ideology follows the logic of spatial voting laid out by Downs (1957): closed primaries feature more partisan electorates and attract more ideologically extreme candidates, while the ideologically diverse electorates of open primaries attract more moderate candidates Ansolabehere, Snyder and Stewart, 2001, Burden, 2004; Fiorina, 1999). However, other scholars argue that this relationship is not as clear as the Downsian story predicts and that different rules may lead to outcomes that defy Downsian logic (McGhee et al., 2014; Kanthak and Morton, 2001).

Knowing which constituency candidates are more responsive to is the first step towards understanding how candidates campaign in general elections. Few studies have examined the relationship between a primary candidate's ideology, the electorate's ideology, and which candidate wins the primary. Brady, Han and Pope (2007) find that ideologically extreme primary incumbents have higher margins of victory and that moderate incumbents are more likely to draw primary challengers. Brady, Han and Pope (2007) represents an important systematic look at the role of primaries but does not address the role of primary electorate ideology.

Our main goal is to examine whether a candidate's primary electorate has an independent effect on his or her ideological orientation. We argue that because primaries have become a necessary jumping-off point to electoral success, candidates will strategically appeal to their primary constituents. In order to prove that primary electorates have a distinct effect on the ideological orientation of their candidates, we posit two hypotheses:

- Hypothesis 1: Ideologically extreme primary electorates are correlated with ideo- 
logically extreme primary election candidates.

If candidates are strategic about aligning towards their primary constituents, then extreme primary electorates should generate extreme primary candidates. We also test whether primary electorates are choosing candidates based on their relative ideological extremity. This leads to our second hypothesis:

- Hypothesis 2: Ideologically extreme candidates are more likely to win the primary election than moderate candidates.

We expect that highly ideological candidates have a better chance of winning their primaries. If primary electorates do indeed tend to be ideologically extreme, then these electorates should select similarly ideologically extreme primary winners.

\section{Data and Methods}

Until recently our hypotheses had been difficult to test. District level primary election survey data is scarce and has not been representative enough to study multiple congressional districts. Previous studies have relied on samples of congressional districts that are not nationally representative (Gerber and Lewis, 2004). Ideal point estimations for congressional candidates are also limited. Ideology measures like DW-NOMINATE are available only for office-holders, not for candidates who ran for election but did not win. Other scholars have tried to address this by using self-reported measures of candidate ideology (Burden, 2004) or estimating ideology measures themselves (Stone, Maisel and Lowman, 2012). Both methods are subject to bias, do not provide a consistent measure of ideology across districts and elections, and do not incorporate the ideologies of candidates' electoral constituencies.

We use new data sources that address all of these shortcomings and allow us to explore the relationship between primary electorates and candidates in a more rigorous fashion. 
First, we measure the ideology of primary candidates using data from Adam Bonica (Bonica, 2013). His IRT count model uses joint maximum likelihood estimation to estimate ideology scores for candidates who received money from at least 30 unique contributors during their election cycle. These candidate ideology scores are estimated based on the ideology of the campaign contributors. Like DW-NOMINATE scores, the Bonica ideology estimates map candidates onto a liberal-conservative scale from -3 (most liberal) to +3 (most conservative) using data on individual contributions from the Federal Election Commission ${ }^{1}$. The Bonica ideology scores presume that political actors prefer ideologically proximate outcomes to non-proximate outcomes; other spatial models of political preferences, like DW-NOMINATE, make this same assumption. The Bonica ideology scores are ideal for use in our study because they give us data on a wide range of congressional candidates, not just those who won. By including all candidates for party nomination in our dataset rather than just candidates who eventually won their elections, we improve the explanatory power of our model over previous models.

We measure the ideology of a candidate's different electoral constituencies using survey data from the 2008 and 2010 Cooperative Congressional Election Study (CCES). The CCES asked a variety of questions, including the respondent's self-reported ideology on a seven-point scale and whether the respondent voted in a party primary and the general election, to a nationally-representative sample of 30,000 respondents in 2008 and 55,000 respondents in 2010. The large CCES sample sizes allow us to aggregate respondents' ideology scores in each congressional district for the following groups:2

- Primary electorate extremity: average ideology of the people who voted in the candidate's partisan primary election.

${ }^{1}$ These scores also do not include contributions from PACs or other political groups as well as contributions under $\$ 200$. Full details about how he generates this measure can be found in Bonica (2013).

${ }^{2}$ The supplementary appendix also includes descriptive statistics and discusses our findings on how our CCES data complement other studies of the ideologies of primary and general election voters. 
- Partisan general electorate extremity: average ideology of the people of the candidate's party who voted in the general election.

- General electorate extremity: average ideology of all people who voted in the general election in the candidate's district, or the district's median voter.

Most of our analysis uses the absolute values of the Bonica candidate ideology scores and the district ideology scores; this allows us to compare relative ideological extremity regardless of the direction of the extremity.

We include a series of control variables in our models $3^{3}$ These control variables account for candidate type (Jacobson, 1990; Jacobson and Kernell, 1983) by measuring whether the candidate is an incumbent, a challenger, or in an open seat election $\bigsqcup^{4}$ and whether the candidate has previously held elected office 5 . We control for open and closed primaries: ${ }^{6}$ the district's Cook PVI score and the competitiveness of the primary election: $: 7$ and the candidate's party identification, a binary variable indicating whether the candidate is a Republican.

We use regression analysis to evaluate whether primary electorate ideology influences a candidate's ideology and probit regression analysis to assess whether ideologically extreme candidates are more likely to win their party's nomination. These results allow

${ }^{3}$ Much of this data was collected from the America Votes series published by the CQ Press and was coded and shared with us by Stephen Pettigrew.

${ }^{4}$ The variables for incumbent, challenger, and open election are mutually exclusive. The challenger variable serves as the baseline category in the OLS model. We define open seats as cases in which a party does not have an incumbent representative seeking nomination.

${ }^{5}$ This variable does not include current incumbents.

${ }^{6}$ Open primaries allow voters of any party affiliation to participate; closed primaries allow only party registrants; semi-open primaries allow party registrants and unaffiliated voters (Gerber and Morton, 1998; Kaufmann, Gimpel and Hoffman, 2003: McGhee et al. 2014). We exclude all nonpartisan primaries.

'The Cook PVI score measures how strongly a congressional district leans towards the Republican or Democratic Party. We define district competitiveness as the margin of victory the winning candidate achieved over the second-place candidate. Highly competitive elections are scaled as 100 . 
Figure 1: Ideology of Different Candidate Types
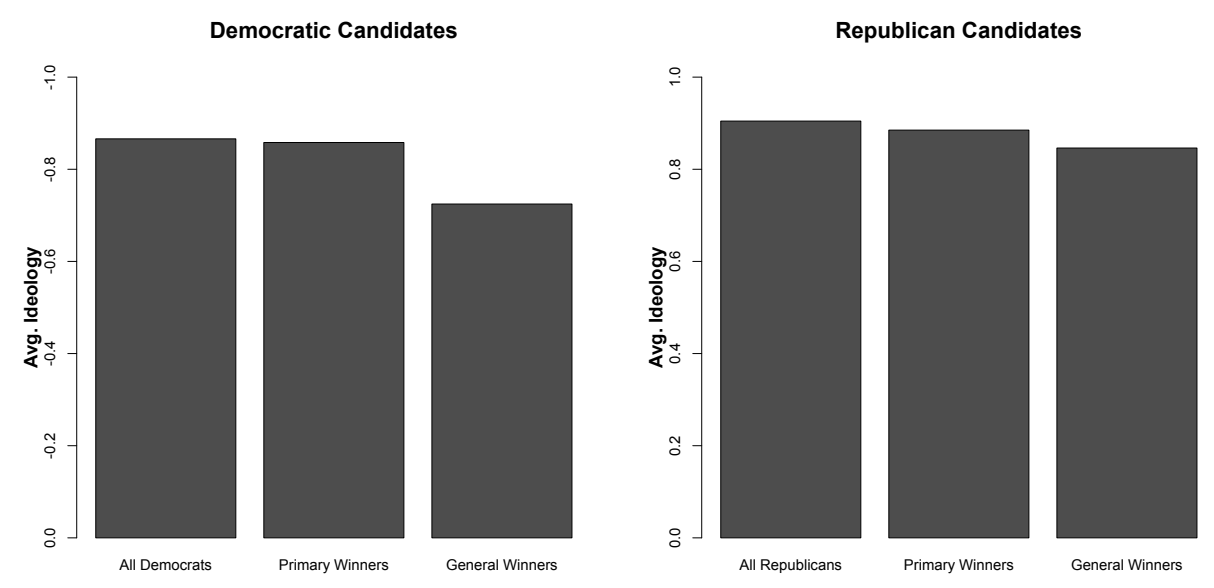

us to evaluate primary election dynamics and how they influence general elections.

\section{Findings}

We first examine the ideologies of candidates for U.S. Congress in Figure 1, which shows differences between candidates who run for primaries, those who win primaries, and those who eventually win general elections. This figure compares Democratic and Republican candidate ideologies in the 2008 and 2010 House elections. For Democrats, primary election candidates and winners are significantly more ideologically extreme than general election winners. Elected Democrats are 0.12 points more centrist than primary winners $(p<0.01)$. The differences between Republican candidates are less noticeable; Republican general winners are 0.04 points more centrist than primary winners and candidates. Republicans are slightly more extreme than Democrats, particularly general election winners (Republicans 0.11 points more extreme than Democrats). This figure demonstrates that primary candidates and winners are more ideological than general election winners. In addition, for both parties, the primary winners are significantly 
Figure 2: Ideology of Different Candidate Types
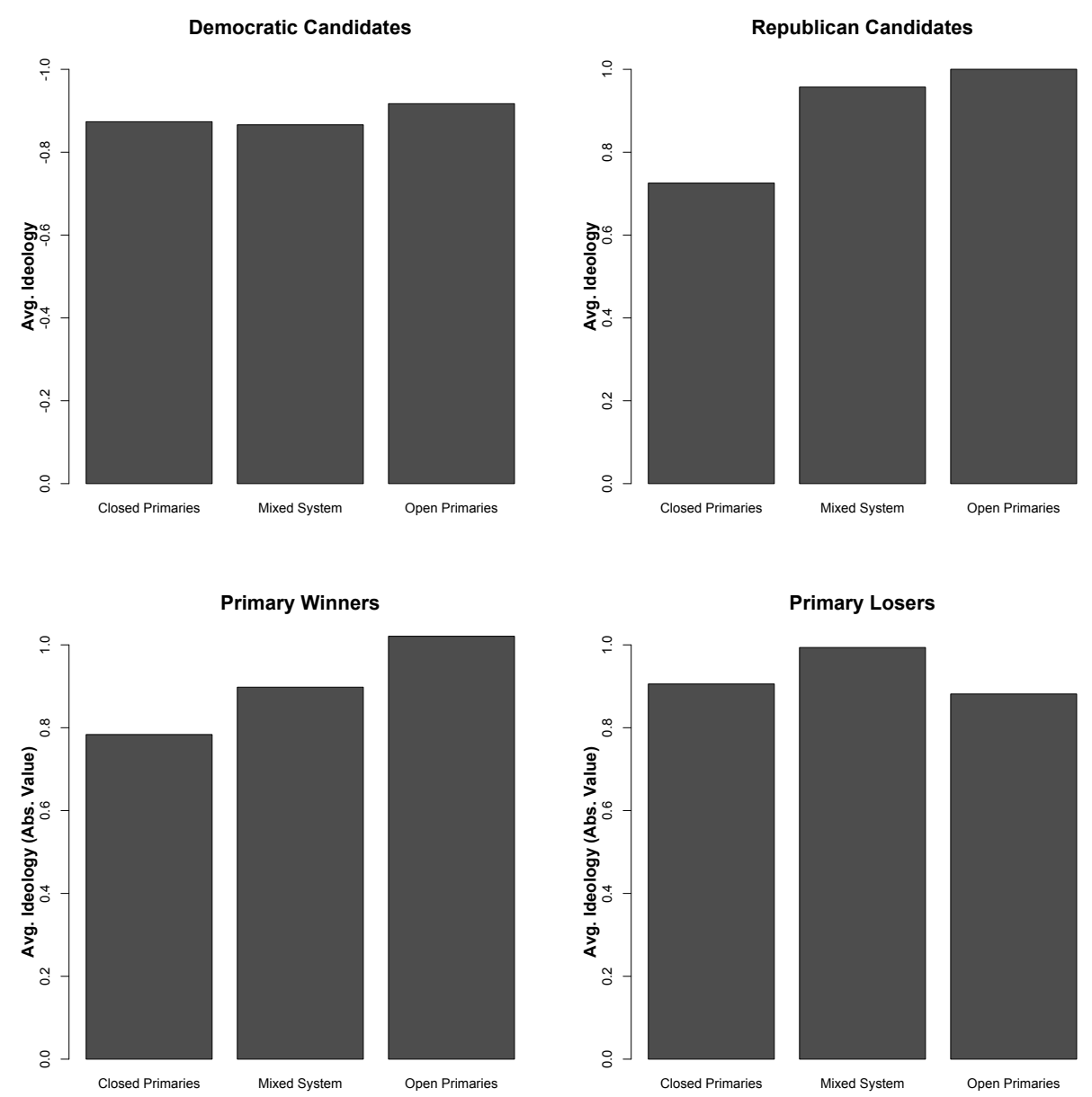

more ideologically extreme than the general election winners $(p<0.01)$.

Figure 2 compares the ideologies of primary candidates and winners and general winners according to what type of election they ran in. While some literature Gerber and Morton, 1998; Kaufmann, Gimpel and Hoffman, 2003) concludes that open primaries have a moderating effect on candidates, we find the opposite. Closed primaries produce the most moderate Democratic and Republican candidates, and open systems produce more ideologically extreme candidates. Our findings confirm previous research (McGhee et al. 2014) which finds that open primaries do not, in fact, produce 
more politically moderate candidates because there are very few people who actually choose to cross over and vote in another party's primary election. Among primary winners, closed primaries attract more moderate candidates, while among primary losers, candidates in mixed system appear to be more extreme. This result may seem counterintuitive, given conventional wisdom about closed primaries restricting the electorate to a more insular and activist party base. Hassell (2012) posited that party elites exert more influence over candidate selection in closed primaries. Given that party elites are primarily concerned with winning and support candidates close to the median voter, closed primaries may generate less extreme candidates. Parties may exert less control over primary losers, which may explain why there is significant variation in the extremity of losing candidates by primary type.

We next use OLS regression analysis in Table 1 to address our hypothesis that there is a positive correlation between primary electorate and primary candidate ideology. Model 1 shows findings for all candidates, Model 2 shows the results for Republicans, and Model 3 shows the results for Democrats 9 The independent variables in these models are the three electoral ideology variables and the control variables described in the Data and Methods section. This table shows that the ideology of a district's primary electorate has a statistically significant influence on the ideology of primary election candidates. A 1-point increase in the district's primary electorate ideology results in a 0.074-point increase in a primary candidate's ideology score - as the primary electorate's ideology becomes more extreme, so does the candidate's ideology $(p<0.05)$. However, other factors have larger effects on primary candidate extremity - the partisan general electorate extremity, incumbency, and the candidate's party. The negative co-

\footnotetext{
${ }^{8}$ We restrict our analysis in this table to primaries that had at least 30 party registrants in the CCES sample to avoid drawing statistically invalid conclusions.

${ }^{9} \mathrm{We}$ also fit the model using random effects and fixed effects at the district level. The results from those models resemble the results in Table 1 with minor variations in coefficients but no changes in statistical significance.
} 
Table 1: Regression of Candidate Extremity Scores on Electoral Variables for 2008 and 2010 Elections

\begin{tabular}{lccc}
\hline Variables & All Candidates & Republicans & Democrats \\
\hline Primary Electorate Extremity & $0.074 *$ & 0.011 & $0.148 * *$ \\
Partisan General Electorate Extremity & $(0.031)$ & $(0.036)$ & $(0.053)$ \\
& $0.203 *$ & $0.134 *$ & $0.190 * *$ \\
General Electorate Extremity & $(0.038)$ & $(0.052)$ & $(0.061)$ \\
& 0.010 & 0.002 & -0.060 \\
Incumbent & $(0.040)$ & $(0.051)$ & $(0.073)$ \\
& $-0.267 * *$ & $-0.245 * *$ & $-0.324 * *$ \\
Unchallenged & $(0.055)$ & $(0.069)$ & $(0.091)$ \\
& 0.061 & -0.040 & 0.113 \\
Open Election & $(0.046)$ & $(0.055)$ & $(0.077)$ \\
& 0.047 & 0.023 & 0.124 \\
Primary Competitiveness & $(0.051)$ & $(0.062)$ & $(0.086)$ \\
& -0.000 & -0.001 & -0.000 \\
District Cook PVI & $(0.000)$ & $(0.000)$ & $(0.001)$ \\
& $0.003 *$ & $0.013 * *$ & -0.002 \\
Previous Officeholder & $(0.001)$ & $(.002)$ & $(0.002)$ \\
& $-0.080 * *$ & $-0.082 * *$ & -0.093 \\
Closed Primary & $(0.030)$ & $(0.030)$ & $(0.067)$ \\
& $-0.129 * *$ & $-0.162 * *$ & -0.044 \\
Open Primary & $(0.025)$ & $(0.029)$ & $(0.043)$ \\
& 0.048 & $0.093 *$ & 0.025 \\
2008 & $(0.034)$ & $(0.039)$ & $(0.058)$ \\
& $-0.064 *$ & -0.036 & $-0.114 *$ \\
Republican & $(0.027)$ & $(0.032)$ & $(0.047)$ \\
Constant & $-0.260 * *$ & & \\
& $(0.036)$ & & \\
No of Obs & $0.834 * *$ & $0.761 * *$ & $0.859 * *$ \\
Adj R-squared & $(0.081)$ & $(0.121)$ & $(.141)$ \\
\hline N & 938 & 587 & 351 \\
& .1970 & .2248 & .2727 \\
\hline
\end{tabular}

${ }^{*}$ prob $<.05,{ }^{* *}$ prob $<.01 ;$ SE in parentheses 
Figure 3: Means and Standard Deviations of Republican and Democratic Candidate Extremity Scores

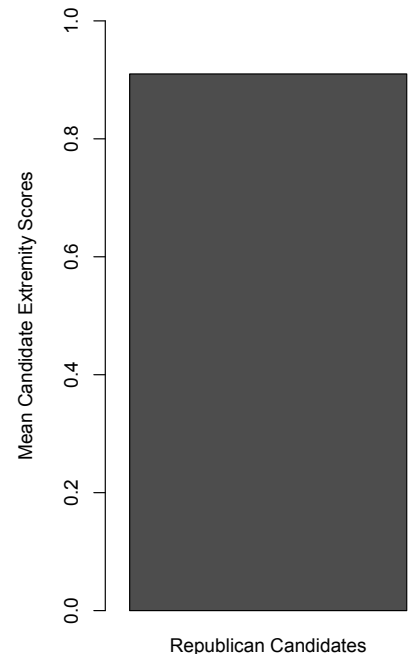

Republican Candidates

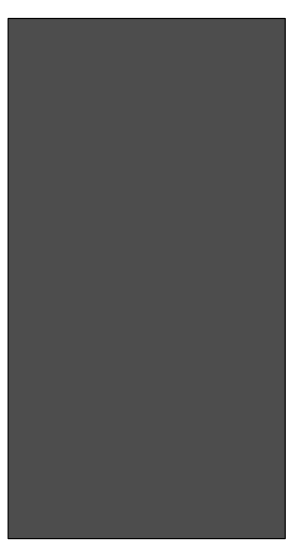

Democratic Candidates

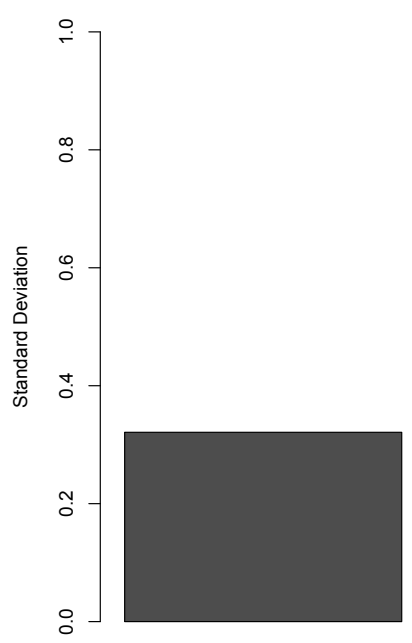

Republican Candidates

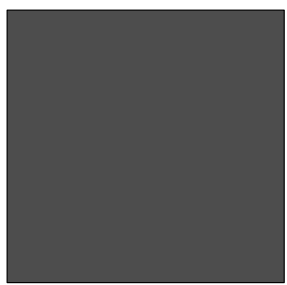

Democratic Candidates

efficient on the latter variable is likely the result of the ideological uniformity of Republican candidates. Figure 3 shows a bar graph comparison of mean candidate extremity scores and their standard deviations broken down by Republicans and Democrats. The Republican candidates' mean is higher than the Democratic mean, but the standard deviation is much lower $(p<0.001)$, reflecting a lack of ideological diversity among Republican candidates.

In addition to the district ideology variables, there were other statistically significant control variables in Table 1 . We found a small positive correlation between a candidate's ideology and the district's Cook PVI score $\mathrm{Q}^{10}$ and a slight negative correlation with closed primaries, which reflects the results in Figure 2. Primary electorates exert only a small

${ }^{10}$ Since Cook PVI measures a district's presidential voting patterns, this shows that candidates are responsive to their district's national voting behavior. This finding is significant for Republicans, indicating that more conservative Republicans are more drawn towards districts which were more Republican in their presidential voting. 
influence on candidate ideology, but it is nonetheless statistically significant in the face of other control variables. Primary candidates respond to their primary electorate's ideology even once the ideologies of their general electorates are accounted for. This finding provides evidence supporting Hypothesis 1 and shows that there is a statistically significant and positive relationship between the primary electorate's ideology and a primary candidate's ideology.

However, the nature of this relationship depends on the electorate's and candidate's partisanship. We show this by running separate models for Republican and Democratic candidates in Table 1. Our results show that Democratic candidates respond to their primary and partisan general electorates while Republican candidates respond only to their partisan general electorates. In addition, Republican party electorates have a 50 percent larger influence on their candidates than Democratic electorates. The ideology of the general electorate as a whole is not significant in either model. Incumbency is significant in both models and has a moderating effect on a candidate's ideology. In addition, several other control variables are statistically significant in the Republican model.

The most interesting question arising from Table 1 is why Republican candidates are responsive only to their partisan general electorate while Democrats are responsive to both their primary and partisan general electorate. The answer may be found in Figure 4. which shows the distributions of the four ideology variables split between Democrats and Republicans. The panels displaying the distributions for primary electorates, partisan general electorates, and candidates show sharp distinctions between Republicans and Democrats. The median Republican electorate scores are nearly 1 point higher than the median Democratic scores, and the median Republican general electorate is 0.5 points more extreme than the median Democratic general electorate. Republicans also have a far lower standard deviation in each of these distributions than Democrats. There are also differences between candidate ideologies. Democratic candidates have a 
Figure 4: Distribution of Candidate and Electorate Extremity
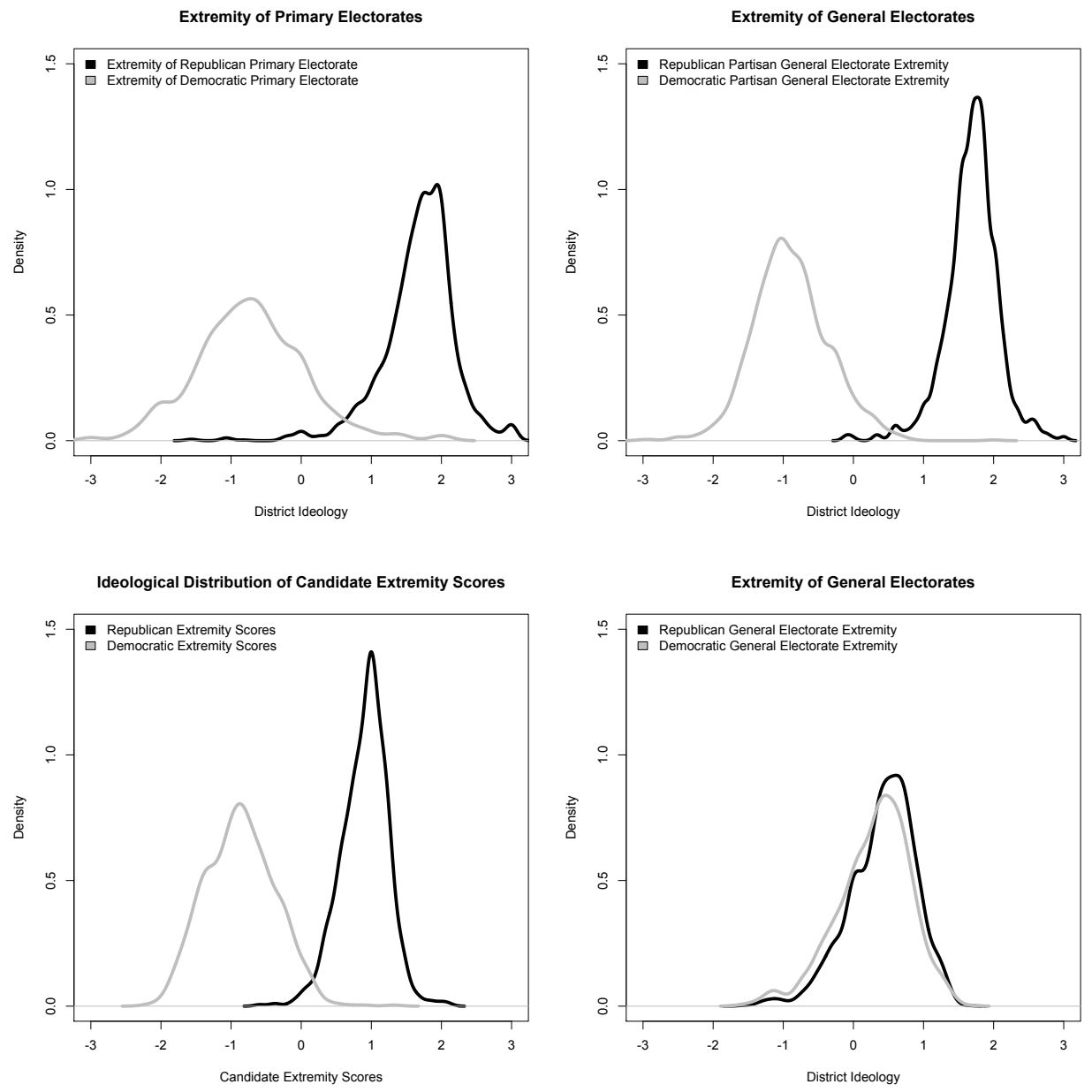

median ideology score of -1 , and Republican candidates have a median ideology score of +1 , but Republican candidates have a far smaller standard deviation than Democrats. For Republican electorates and candidates, there simply is not much variance for our models to explain. These results indicate that Republican candidates and electorates are more stringently ideological when compared to Democrats.

As we have found evidence in favor of Hypothesis 1, we now turn to Hypothesis 2, which posits that extreme candidates are more likely to win in primaries. The results of a probit regression model to test this hypothesis are shown in Table 2[11 The

${ }^{11}$ We limit the analysis in Table 2 to contested primary elections. Races where there 
Table 2: Probit Model of Primary Win on Electoral Variables for 2008 and 2010 Elections

\begin{tabular}{lccc}
\hline Variables & All Candidates & Republicans & Democrats \\
\hline Candidate Extremity & 0.096 & $0.450 *$ & 0.080 \\
& $(0.164)$ & $(0.233)$ & $(0.224)$ \\
Incumbent & $0.845 * *$ & $0.792 *$ & $0.871 * *$ \\
& $(0.216)$ & $(0.315)$ & $(0.307)$ \\
Challenger & $-0.503 *$ & -0.469 & -0.637 \\
& $(0.241)$ & $(0.350)$ & $(0.345)$ \\
Previous Office & $0.556 * *$ & $0.601 * *$ & $0.483 *$ \\
& $(0.136)$ & $(0.168)$ & $(0.237)$ \\
Relative Campaign Spending & $0.037 * *$ & $0.042 * *$ & $0.033 * *$ \\
& $(0.002)$ & $(0.002)$ & $(0.003)$ \\
Constant & $-2.231 * *$ & $-2.771 * *$ & $-1.777 * *$ \\
& $(0.213)$ & $(0.306)$ & $(0.315)$ \\
\hline No of Obs & 993 & 631 & 362 \\
Pseudo R-squared & 0.6058 & 0.6125 & 0.6031 \\
\hline
\end{tabular}

*prob<.05, ${ }^{* *}$ prob $<.01 ;$ SE in parentheses

dependent variable in these models measures whether the candidate won the primary, and the independent variables measure the candidate's ideology, whether the candidate has previously held elected office and is a challenger or incumbent (with open seats being the excluded category), and the candidate's campaign spending relative to their opponents 12

We find partial support for Hypothesis 2. In Model 1 of Table 2, the candidate ideology measure is not statistically significant while other variables (incumbency, previous elected office, relative campaign spending) are. In other words, incumbents, prior office holders, and heavy spenders tend to win their primaries. However, candidate ideology is significant in the Republican model, and the coefficient is positive and fairly large. This indicates that more ideological Republican candidates are more likely to win their primaries. However, we do not find the same effect among Democrats. This finding makes sense in light of the analysis in Table 1 and Figures 3 and 4, which show was a candidate unchallenged in the primary were dropped.

${ }^{12}$ We also ran a version of this table that interacted the candidate's ideology with the primary electorate ideology; this analysis has been placed in the supplementary appendix. 
that Republicans and Democrats demonstrate different ideological patterns. Since Republican electorates and candidates tend to be more extreme than their Democratic counterparts, ideological extremity matters more to winning party nomination for Republicans than for Democrats. While Republican primary electorates care more about the ideological purity of their candidates, Democratic primary electorates appear to select their nominees using a different set of qualifications.

\section{Discussion and Conclusions}

We show that primary electorate ideology is a significant predictor of a candidate's ideology. Furthermore, Democratic and Republican candidates and voters show different ideological patterns: Republicans are more extreme than Democrats, and there is little ideological diversity among the party's candidates or electorates. Republican candidates tend to be ideologically responsive to their partisan general electorate while Democratic candidates are responsive to their primary and partisan general electorates. Lastly, more ideologically extreme Republican candidates are more likely to win their party's nomination in the primary election.

We recognize that the 2008 and 2010 elections represent an extremely polarized era (Jacobson, 2012). It is possible that our results are partly driven by this polarization, especially amongst Republican candidates. The lack of ideological diversity among Republican candidates reflects the relative ideological extremity of Republican voters, especially primary voters. It is possible that if this study was run in an era of more ideological diversity within the Republican electorate, we might have seen more responsiveness among Republican candidates to their primary constituencies. In addition, these results might change if the nature of the electorate and the candidates it attracts changes in the future.

Given the nature of our study, it is difficult to determine whether politicians are 
prospective in adjusting their platforms to relevant electorates or whether electorates are a signal that encourages more like-minded candidates to seek office. Given trends in polarization among long-term incumbents and a general polarization among candidates who seek office, it is likely that electorates influence candidate positioning in a combination of these ways. The incorporation of more data over more years would allow researchers to examine this question in more detail.

These findings indicate that candidates for Congress tend to respond only to the ideological leanings of voters from their party instead of paying attention to voters from the other party, which may have troubling implications for how members of Congress represent their constituents. The trend of primary electorates choosing extreme candidates could lead to a lack of ideological congruence between members of Congress and their general election constituencies (Bafumi and Herron, 2010) as moderate voters are disincentivized from voting (Callender and Wilson, 2007), thus further reinforcing recent trends towards political polarization among both elected officials and rank-and-file voters (Stone, Maisel and Lowman, 2012).

Our findings emphasize the importance of primaries in determining the electoral environment of the general election. Primaries determine which candidates run in the general election and which electoral constituency the candidates appeal to. In some congressional districts that are dominated by one party, primaries are essentially the only way the electorate can hold elected officials accountable for their conduct. While the CCES has made strides towards providing primary election data, the discipline's understanding of primary elections will increase only if future surveys ask questions regarding voters' behavior in primaries. Studies that use only general election data are not capturing the full picture of electoral dynamics in the United States. 


\section{References}

Abramowitz, Alan I. and Kyle L. Saunders. 2008. "Is Polarization a Myth?" Journal of Politics 70(2):542-555.

Ansolabehere, Stephen, J. M. Snyder and C. Stewart. 2001. "Candidate Positioning in US House Elections." American Journal of Political Science 45:136-159.

Bafumi, Joseph and Micahel C. Herron. 2010. "Leapfrog Representation and Extremism: A Study of American Voters and Their Members in Congress." American Political Science Review 104:519-542.

Besley, Timothy and Anne Case. 2003. "Political Institutions and Policy Choices: Evidence from the United States." Journal of Economic Literature 41(1):7-73.

Bonica, Adam. 2013. "Ideology and Interests in the Political Marketplace." American Journal of Political Science 57:294-311.

Brady, David W. and E. P. Schwartz. 1995. "Ideology and Interests in Congressional Voting: The Politics of Abortion in the US Senate." Public Choice 84:25-48.

Brady, David W., Hahrie Han and Jeremy C. Pope. 2007. "Primary Elections and Candidate Ideology: Out of Step with the Primary Electorate?" Legislative Studies Quarterly 37(1):79-105.

Burden, Barry C. 2004. "Candidate Positioning in US Congressional Elections." British Journal of Political Science 34:211-227.

Calcagno, Peter T. and Christopher Westley. 2008. "An Institutional Analysis Of Voter Turnout: The Role Of Primary Type And The Expressive And Instrumental Voting Hypotheses." Constitutional Political Economy 19(2):94-110.

Callender, Steven and Catherine H. Wilson. 2007. "Turnout, Polarization, and Duverger's Law." Journal of Politics 69:1047-1056.

Downs, Anthony. 1957. An Economic Theory of Democracy. Harper and Row.

Fenno, Richard F. 1978. Homestyle: House Members in Their Districts. Boston: Little Brown.

Fiorina, Morris P. 1999. "Whatever Happened to the Median Voter?" Technical Report, Stanford University.

Fiorina, Morris P., Samuel Abrams and Jeremy C. Pope. 2006. Culture War? The Myth of a Polarized America. New York:Longman.

Gerber, Elisabeth R. and Jeffrey B. Lewis. 2004. "Beyond the Median: Voter Preferences, District Heterogeneity, and Political Representation." Journal of Political Economy 112(1364-1383). 
Gerber, Elisabeth R. and Rebecca B. Morton. 1998. "Primary Election Systems and Representation." Journal of Law, Economics, and Organization 14:304-324.

Hassell, Hans J. G. 2012. "The Party's Primary." Presented at the 2012 meetings of the Midwest Political Science Association.

Jacobson, Gary C. 1990. The Electoral Origins of Divided Government: Competition in U.S. House Elections, 1946-1988. Boulder: Westview Press.

Jacobson, Gary C. 2004. The Politics of Congressional Elections. New York City: Pearson Publishers.

Jacobson, Gary C. 2012. "The Electoral Origins of Polarized Politics: Evidence from the 2010 Cooperative Congressional Election Study." American Behavioral Scientist 56:1612-1630.

Jacobson, Gary C. and Samuel Kernell. 1983. Strategy and Choice in Congressional Elections. Yale University Press.

Jewell, Malcolm. 1984. Parties and Primaries: Nominating State Governors. New York: Praeger.

Kanthak, K. and Rebecca B. Morton. 2001. The Effects of Primary Systems on Congressional Elections. Rowan and Littlefield.

Kaufmann, Karen M., James G. Gimpel and Adam H. Hoffman. 2003. "A Promise Fulfilled? Open Primaries and Representation." Journal of Politics 65:457-476.

Keele, Luke J. and James A. Stimson. 2005. "Independents and Party Polarization." Presented at the 2005 meetings of the American Political Science Association.

King, David C. 2003. "Congress, Polarization, and Fidelity to the Median Voter." Working Paper.

Mayhew, David R. 1974. Congress: The Electoral Connection. Yale University Press.

McGhee, E., S. Masket, B. Shor, S. Rogers and N. McCarty. 2014. "A Primary Cause of Partisanship? Nomination Systems and Legislator Ideology." American Journal of Political Science 58:337-351.

Stone, Walter J., L. Sandy Maisel and Trever C. Lowman. 2012. The Parties Respond: Changes in American Parties and Campaigns. Boulder: Westview Press chapter Boehner's Dilemma: A Tempest in a Tea Party?

Westley, Christopher, Peter T. Calcagno and Richard A. Ault. 2004. "Primary Election Systems and Candidate Shirking." Eastern Economic Journal 30(3):365-376. 